\title{
Effective tracking of nationally determined contributions: A case study on South Africa
}

\author{
K. Ross ${ }^{1 *}(\mathbb{D})$, H. Winkler ${ }^{2}$ \\ 1. World Resources Institute, Washington, D.C., U.S.A. \\ 2. Faculty of Engineering and the Built Environment and African Climate and Development Initiative, \\ University of Cape Town, Cape Town, South Africa
}

\begin{abstract}
The Paris Agreement's enhanced transparency framework requires that all Parties track and report progress toward their nationally determined contributions (NDCs). This paper develops a qualitative, multicriteria framework that can be used to either design effective NDC tracking systems or evaluate the extent to which Parties are prepared for NDC tracking. The paper also applies the framework to a case study on South Africa, with results indicating that the country is progressing well in terms of selecting appropriate indicators, enacting legislation, and enhancing transparency. In areas of collecting data, reporting on socioeconomic outcomes, and making changes in national policy, there is room for improvement, and the paper explores options to this end. Since South Africa has a relatively advanced system for tracking mitigation goals, the findings of the paper suggest that other developing country Parties may require additional resources and capacity to track NDCs effectively.
\end{abstract}

Journal of Energy in Southern Africa 32(2): 11-25

DOI: https://dx.doi.org/10.17159/2413-3051/2021/v32i2a8744

Published by the University of Cape Town ISSN:2413-3051 https://journals.assaf.org.za/jesa

This work is licensed under a Creative Commons Attribution-ShareAlike 4.0 International Licence

Sponsored by the Department of Science and Innovation

Corresponding author: Tel.: +1 (202) 729 7621; email katie.ross@wri.org 


\section{Introduction}

In 2015, the Paris Agreement established an enhanced transparency framework for action and support (United Nations Framework Convention on Climate Change (UNFCCC) 2015; Article 13). The objective of the framework is to provide a clear understanding of climate change action; that is, to understand progress toward individual Parties' contributions, as well as the collective goals agreed to under the Paris Agreement. The enhanced transparency framework requires that all Parties track and report progress in implementing their nationally determined contributions (NDCs) (UNFCCC 2015, Article 13.7(b)). A precise interpretation of the Article 13.7(b) implies that the scope of NDC tracking is mandatory for mitigation only (Winkler et al. 2017). ${ }^{1}$

In 2018, Parties agreed on the modalities, procedures, and guidelines (MPGs) that will guide the implementation of the enhanced transparency framework (UNFCCC 2018). The MPGs include guidance for tracking progress made in implementing and achieving NDCs, which again focus on mitigation only (UNFCCC 2018; paragraphs 65-79). The MPGs for NDC tracking provide both obligations and flexibility for Parties. Specifically, this means that the MPGs have language that suggests mandatory reporting ('shall'), as well as qualifiers ('as appropriate' or 'as applicable', etc.), which provide guidance for Parties on what would be good practice (Winkler et al. 2019). All Parties are required to report on progress toward their NDC as part of their biennial transparency reports, the first of which is to be submitted to the UNFCCC by the end of 2024 at the latest (UNFCCC 2018).

In recent years, some developing country Parties have advanced domestic arrangements for mitigation goal tracking and reporting, as demonstrated through consecutive submissions of biennial update reports (BURs), which are the primary vehicle for reporting internationally on progress toward mitigation goals, policies and actions (UNFCCC 2020). The body of literature for mitigation goal tracking has also grown exponentially since the adoption of the Bali Action Plan in 2007 (UNFCCC 2007). In early years, scholars expanded ideas for measurement, reporting, and verification, by providing clearer definitions of how it is constituted, as well as the responsibilities and processes for conducting it (Breidenich and Bodansky, 2009; Fransen 2009; Ellis and Moarif 2009; Niederberger and Kimble 2011; Pew Center 2010; Winkler et al. 2008). After the Paris Agreement was adopted, policymakers deepened thinking on the MPGs, including means of enhancing transparency (Briner and Moarif 2017), information needed to facilitate the clarity, transparency, and understanding of mitigation contributions (Moarif 2017), possible structures of mitigation-related MPGs (Briner and Moarif 2017), accounting for mitigation targets in NDCs (Hood and Soo 2017), and mapping the linkages between the transparency framework and other provisions of the Paris Agreement (Dagnet et al. 2017a; Dagnet et al. 2017b).

At the same time, many developing country Parties still remain ill-prepared for the complex nature of mitigation goal tracking (Briner and Moarif 2016). For example, at the end of 2020, 100 developing country Parties had not yet communicated a first BUR, while 63 had submitted a first, 31 a second, 13, a third and 5 a fourth BUR (UNFCCC 2020). The transition to biennially reporting on progress toward NDCs from 2024 onward will represent a substantial step-up for these countries and may impose additional obligations beyond their current capacities.

In light of these capacity constraints, it becomes important to investigate whether NDC tracking systems can be designed to assist with meeting domestic objectives, while also meeting international reporting obligations. For example, can NDC tracking help to inform domestic policy and decision-making? Can it help motivate further climate action? Can it help to promote trust and accountability amongst domestic actors? With the MPGs only recently agreed, there is limited practical guidance available for Parties.

In this context, this paper aims to develop a structured approach for designing an NDC tracking system that responds to both domestic needs and the MPGs - in essence, a framework for 'effective' NDC tracking. The qualitative assessment framework comprises eight 'effective' criteria related to NDC tracking, applying to all stages of a typical mitigation goal tracking process. This means that tracking begins with planning, before establishing a means for achieving that vision (where inputs feed into processes, which deliver outputs, supporting the achievement of outcomes), with adaptive management to support regular review and ensure that stated goals are being met. This framework is not intended to be seen as distinct from a country's existing climate change monitoring and reporting system (which is likely to have a broader range, encompassing mitigation, adaptation, and finance tracking), but rather as an approach that can be built into an existing system.

Using South Africa as a case study, and drawing from literature and interviews with key stakeholders, this paper first establishes a qualitative, multicriteria framework for effective NDC tracking (section 2). It then uses the framework to assess South Africa's preparedness for effective NDC tracking and offers recommendations to advance domestic arrangements (section 3). The results reveal key procedural, contextual, and financial constraints to 
future NDC tracking in South Africa and indicate a need to focus efforts on improving capacity and skills, and to connect NDC tracking with broader national policymaking.

The framework developed in this paper is aimed primarily at the entities responsible for NDC tracking in national governments, typically the environment department. In the case of South Africa, this is the monitoring and mitigation unit within the Department of Forestry, Fisheries and the Environment (DFFE). And, while the recommendations presented in this paper are aimed at DFFE, the framework that is developed in this paper has a broader utility in that it complements the MPGs and provides a possible approach to (1) designing effective NDC tracking processes within countries, or (2) evaluating the extent to which Parties are prepared for effective NDC tracking, and identifying areas for enhancing existing climate change monitoring and evaluation systems. The framework is constrained to mitigation only, per the precise interpretation of the MPGs.

\section{A framework for effective NDC tracking}

The MPGs provide guidance for tracking progress toward the implementation and achievement of NDCs. Broadly speaking, Parties are required to select tracking indicators, report on information relevant to those indicators, and provide information on actions, policies and measures that support the implementation and achievement of the NDC (UNFCCC 2018).

While Parties have a long history of reporting information to the UNFCCC (e.g., through national communications), national governments are increa- singly seeing the value of tracking actions to address climate actions, beyond meeting multilateral reporting obligations. If done well, this tracking can support a range of domestic objectives, including promoting climate change action and supporting evidence-based decision making (Aldy 2014; de la Torre et al. 2018).

Program theory typically underpins successful processes to track progress toward climate change goals - for an example, see Lamhauge et al. (2012), who analyse a range of country and development cooperation experiences. This means that goal tracking begins with planning (i.e., identifying the vision and objectives of tracking), before establishing a means for achieving that vision, where inputs feed into processes, which deliver outputs, supporting the achievement of outcomes. Additionally, there is iteration, meaning that outputs and outcomes inform planning, which allows for adaptive management and learning and improvement. The process of regular iteration ensures that tracking is performance-oriented to effectively support the achievement of set objectives (Lamhauge et al. 2012). Drawing from literature, Figure 1 and the text below illustrate program theory applied in the context of NDC tracking - essentially depicting an effective framework for NDC tracking that meets both domestic objectives and the MPG requirements. The top (yellow) section of Figure 1 highlights the formal requirements of the MPGs.

\subsection{Planning}

The planning stage provides information about NDC tracking objectives, with a primary focus on supporting the objectives of the environment de-

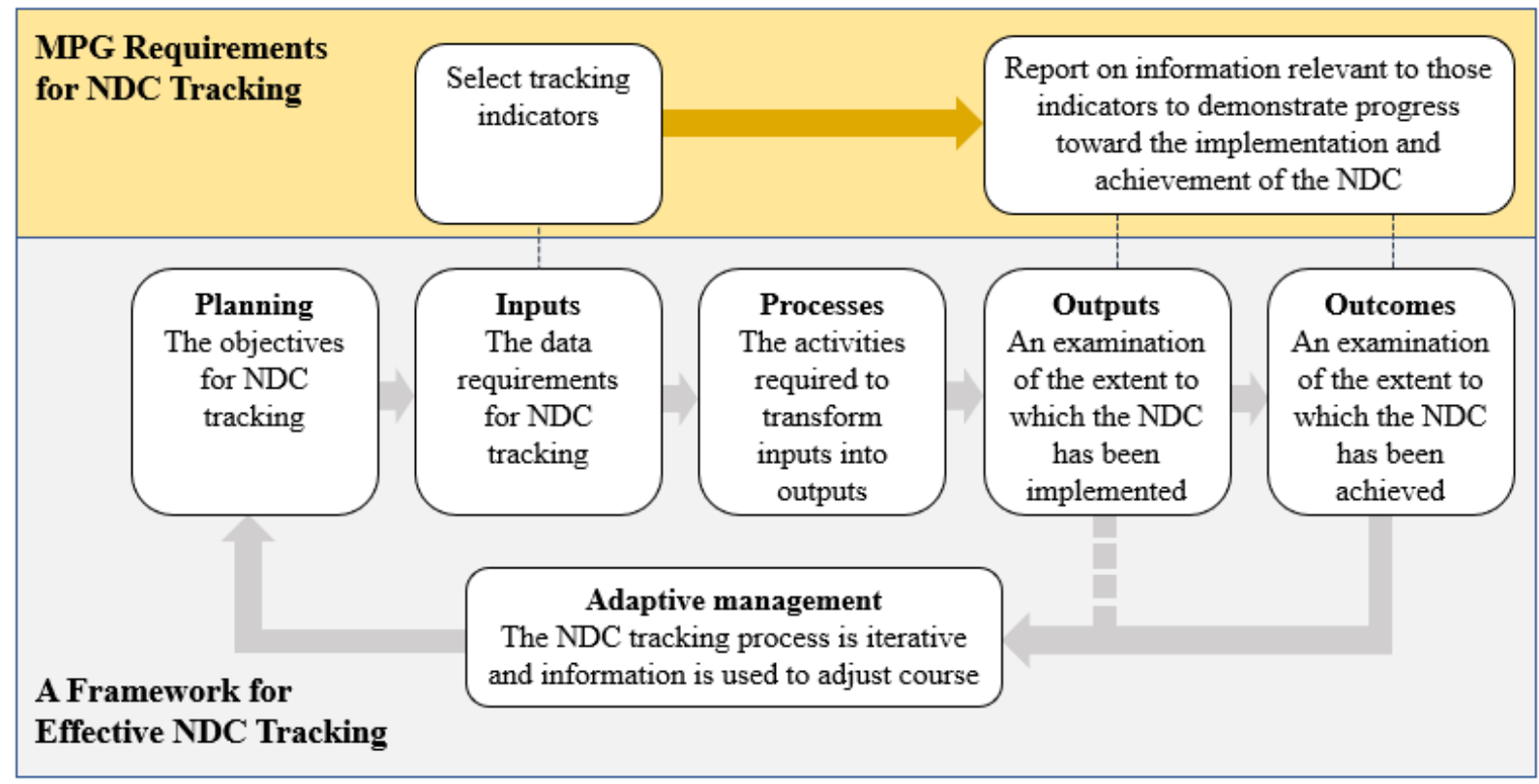

Figure 1: Schematic of the effective NDC tracking framework, with the MPGs highlighted. 
partment in national government rather than all users of mitigation monitoring information. Objectives could include, for example, meeting international reporting requirements, promoting climate action and evidence-based decisionmaking, and/or other domestic priorities.

\subsection{Inputs}

The inputs stage focuses on the data requirements for NDC tracking. These are the indicators used for tracking progress toward the NDCs, which are selected by countries based on international requirements (see UNFCCC 2018, para. 66) and domestic needs. Indicators could, for example, include net GHG emissions and removals, percentage reduction of GHG intensity, and/or relevant qualitative indicators for a specific policy or measure. Per the MPGs, Parties can select their own indicator(s) for tracking NDC progress, which 'shall be relevant to a Party's NDC under Article 4 and may be either qualitative or quantitative' (UNFCCC 2018). Relevance is not defined in the COP decision. The general tone of the MPGs reads 'shall, as appropriate...' which means that, should Parties want to track progress to the best of their abilities (and not because it is legally required), they have a fair amount of facilitative guidance available to them (Winker et al. 2019). Indicators are generally considered to be effective if they are relevant to the desired outcome, precise, and measurable (Klostermann, et al. 2015; Aldy and Pizer 2016).

\subsection{Processes}

The processes stage considers the management processes and activities that are required to transform inputs into outputs, which in turn support the outcomes and goals of NDC tracking. Processes are generally considered to be effective when information collection is a simple as possible and avoids duplication and undue burden (Kusek and Rist 2004) (i.e., the information collected for NDC tracking meets the needs of the indicators outlined in criterion 1), and when there are legal provisions to collect information and protect confidentiality.

\subsection{Outputs}

The outputs stage focuses on the results of NDC tracking and examines the extent to which the NDC has been implemented. Outputs may include current and historical greenhouse gas (GHG) emissions, GHG emissions projections, and assessments of the impacts (GHG and non-GHG) of mitigation policies and actions. Outputs are generally considered effective when (1) governments have sufficient information to evaluate progress toward the mitigation goal and the likelihood of achieving the goal (Levin et al. 2014); (2) govern- ments and other domestic and international stakeholders have a clearer sense of the status of projects, programs, and policies implemented to address climate change (Kusek and Rist 2004); and (3) governments can quantify the socio-economic impacts resulting from climate mitigation actions (a growing body of literature highlights the fundamental role of socio-economic factors in shaping how energy and climate transitions unfold (Markkanen and Anger-Kraavi 2019; Trutnevyte, E. 2019)).

\subsection{Outcomes}

The outcomes stage evaluates the extent to which the NDC is achieved. Outcomes are effective when the NDC is met, or on track to be met. International and domestic stakeholders want to see demonstrable impacts from climate change policies and actions (Kusek and Rist 2004), helping to build trust that the goals are achievable, and that the government is committed to achieving them.

\subsection{Adaptive management}

The outputs and outcomes of NDC tracking should provide useful information to inform decision-making and policy-making. When effective, there should be a clear link between the outputs and outcomes that are produced through NDC tracking and changes in policy direction. For example, if certain mitigation policies and actions are not delivering the expected results, there will be course corrections along the way to address any challenges or barriers (Weiner 2015). Similarly, if certain policies are producing excellent outcomes, this learning will be capitalised upon and employed in other areas. Effective tracking helps to inform policy and decision-making and can be a powerful tool for motivating further action (Winkler et al. 2019).

\subsection{A qualitative, multi-criteria framework for effective NDC tracking}

Table 1 summarises the main results of sections 2.1-2.6 - giving, in essence, a qualitative, multicriteria framework for effective NDC tracking.

\subsection{Ranking scale}

To apply the qualitative, multicriteria framework presented in Table 1, a measurement scale is required to evaluate each criterion. In 1946, Stevens proposed a classification of scales of measurement that is still used today. For this evaluation, an ordinal scale is most appropriate, as it proposes an order/ranking of items and helps evaluate the extent to which something is achieved. Table 2 presents the ordinal measurement scale used for this evaluation. 
Table 1: A qualitative, multi-criteria framework for effective NDC tracking

\begin{tabular}{|c|c|c|}
\hline Element & Effectiveness criteria & Means of verification \\
\hline Inputs & $\begin{array}{l}\text { Criterion 1: The indicators for NDC tracking are relevant to the } \\
\text { desired outcome, and are precise and measurable }\end{array}$ & Indicators \\
\hline \multirow[t]{2}{*}{ Processes } & $\begin{array}{l}\text { Criterion 2: The information collected for NDC tracking meets } \\
\text { the needs of the indicators outlined in criterion } 1\end{array}$ & Information inputs \\
\hline & $\begin{array}{l}\text { Criterion 3: There is legislative support for collecting data for } \\
\text { NDC tracking and protecting confidential information }\end{array}$ & $\begin{array}{l}\text { Regulations and } \\
\text { legislation }\end{array}$ \\
\hline \multirow[t]{3}{*}{ Outputs } & $\begin{array}{l}\text { Criterion 4: The government can evaluate progress toward the } \\
\text { NDC mitigation target by using outputs from the monitoring } \\
\text { and evaluation system }\end{array}$ & Information outputs \\
\hline & $\begin{array}{l}\text { Criterion 5: The government and relevant actors can under- } \\
\text { stand the ambition of, and progress towards, mitigation targets, } \\
\text { actions, and measures }\end{array}$ & Information outputs \\
\hline & $\begin{array}{l}\text { Criterion 6: The government can quantify the socio-economic } \\
\text { impacts resulting from climate mitigation actions }\end{array}$ & Information outputs \\
\hline Outcomes & $\begin{array}{l}\text { Criterion 7: The government presents information that would } \\
\text { enable an assessment of whether the country is on track to } \\
\text { achieve the NDC or, as a proxy, on track to achieve the Copenha- } \\
\text { gen pledge }\end{array}$ & $\begin{array}{l}\text { Current GHG emissions } \\
\text { and an assessment of } \\
\text { the likelihood of goal } \\
\text { achievement }\end{array}$ \\
\hline $\begin{array}{l}\text { Adaptive } \\
\text { manage- } \\
\text { ment }\end{array}$ & $\begin{array}{l}\text { Criterion 8: The NDC tracking process is iterative and infor- } \\
\text { mation is used to adjust its course }\end{array}$ & $\begin{array}{l}\text { Evidence of adaptive } \\
\text { management and con- } \\
\text { tinual improvement }\end{array}$ \\
\hline
\end{tabular}

Table 2: Summary of the ordinal scoring scale

\begin{tabular}{cl}
\hline Score & \multicolumn{1}{c}{ Necessary conditions } \\
\hline$-\quad$ Insufficient evidence to draw a conclusion \\
Evidence suggests that the criterion is not met. This suggests a particular aspect is neglected. \\
$\begin{array}{l}\text { Evidence suggests that the criterion is partly met. This suggests that certain aspects are recog- } \\
\text { nised as important; however, additional consideration may be required to make it truly effective }\end{array}$ \\
\hline
\end{tabular}

The paper now turns to applying the qualitative, multicriteria framework to South Africa, to evaluate the country's preparedness for effective NDC tracking and identify areas for enhancement.

\section{A South African case study 3.1 Background}

South Africa has nearly a decade of experience in tracking mitigation goals. In 2011, South Africa established a monitoring and evaluation (M\&E) system for tracking progress toward climate change goals (Government of the Republic of South Africa (RSA) 2011; DEA 2015). The initial aim of the M\&E system was to improve understanding of the impact of mitigation measures implemented in the country
(RSA 2011). In 2014, the M\&E system was expanded to encompass adaptation and finance tracking (DEA 2015). South Africa's M\&E system includes provisions for regular review to ensure that it continues to meet the needs of the South African government and its stakeholders (DEA 2014).

In September 2015, South Africa submitted its intended NDC (the INDC) to the UNFCCC, with a commitment for GHG emissions to be in the range of 398 to $614 \mathrm{MtCO}_{2}$ e between 2025 and 2030 - essentially restating the country's longstanding 'peak, plateau, and decline' emissions trajectory range (RSA 2015) (Figure 2). The INDC became an NDC upon South Africa's ratification of the Paris Agreement in November 2016. 


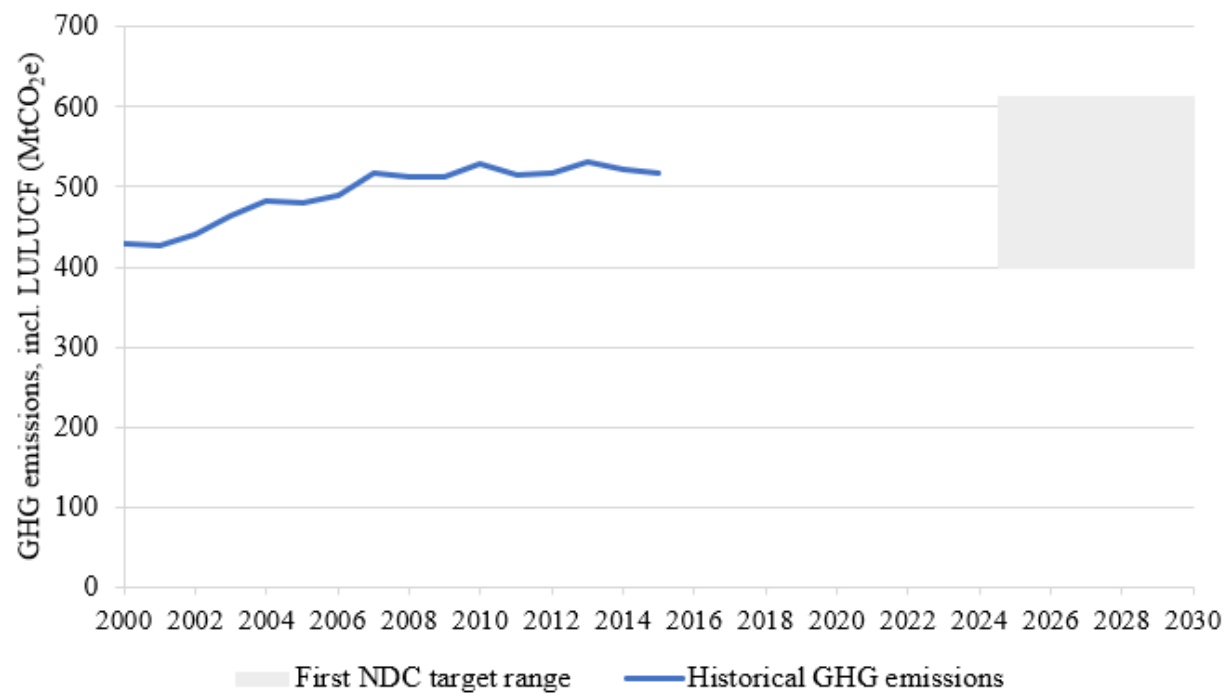

Figure 2: South Africa's historical GHG emissions and mitigation target range in the first NDC. Source: Authors' illustration, based on data from South Africa's GHG National Inventory Report: 2000-2015 (DEA 2019c) for historical GHG emissions, and RSA (2015) for the mitigation target range in the first NDC

South Africa's M\&E system has been developed with an eye on international reporting requirements. When it was first conceptualised and operationalised in 2011, it was with a view to it being 'flexible and dynamic' and to 'evolve with international measuring, reporting, and verification requirements' (RSA 2011). South Africa has also been particularly responsive to developments in this international transparency regime. For example, South Africa published its first annual climate change report in 2016, which explicitly referenced the new international transparency regime and stated that these annual reports will 'institutionalize and systematize South Africa's periodic reporting obligations under the UNFCCC, including the transparency requirements of the new Paris Agreement on NDCs' (DEA 2016). In fact, South Africa's M\&E system appears to have developed in a more sophisticated manner than is required internationally. For example, publicly available documents show that the current M\&E system design will include information flows and analysis from newly planned or adopted climate change policies such as the carbon tax, carbon budgets, and pollution prevention plans (DEA 2019b).

The South African government plans to integrate NDC tracking into its ongoing M\&E system.

\subsection{Applying the qualitative, multicriteria framework to South Africa}

This section presents the results of the application of the NDC tracking framework (i.e., the application of Tables 1 and 2) to South Africa. Before presenting the results, it is important to note that NDC tracking has not yet technically begun in South Africa. While South Africa communicated its intended NDC in 2015, the target period for this contribution only formally commences in 2021, as does implementation of NDCs generally. International reporting on progress toward NDCs is also only expected to start in 2024 (at the latest), through biennial transparency reports (UNFCCC 2018). This evaluation can, nevertheless, assess progress that South Africa is making toward an earlier international mitigation commitment, the Copenhagen Pledge, which was set at the beginning of 2010 to be achieved by 2020 (DEA 2010). Moreover, many of the mitigation measures employed to reach South Africa's NDC target are already well embedded in domestic climate change policy, and some have origins as far back as the 2011 national climate change response white paper. Several of these instruments are already being tracked as part of South Africa's climate change M\&E system. Therefore, the results presented here do not focus on NDC tracking in isolation, but rather appear in the context of a broader examination of South Africa's mitigation M\&E system (i.e., the system that tracks GHG emissions as well as the impacts of mitigation policies and measures), which is expected to continually evolve and improve over the course of NDC implementation.

The results are based on information from two sources: (1) content analysis of public documents, including South Africa's Copenhagen Pledge (DEA 2010), the NDC (RSA 2015), biennial update reports (DEA 2014; DEA 2017a; DEA 2019b), annual climate change reports (DEA 2016; DEA 2017b), government regulations (RSA 2017a; RSA 2017b), the national climate change response M\&E system framework (DEA 2015), and the national climate change response white paper (RSA 2011); and (2) interviews with 11 key stakeholders in South Africa (from government, business, academia, and civil so- 
ciety) to capture relevant background information that is not possible by analysing publicly available documents, including the current status of M\&E in South Africa, the capacity and skills of officials tasked with M\&E, and data collection procedures.

The score for each criterion is shown first, followed by a detailed explanation.

\section{Criterion 1: The indicators for NDC tracking are relevant to the desired outcome, and are precise and measurable}

\section{score:}

Evidence suggests that criterion 1 is fully met. South Africa's M\&E system includes indicators for tracking the country's transition toward a lower-carbon economy, encompassing: (1) sustainable carbon levels, which are measured by GHG emission levels, changes in GHG emissions, mitigation impact of mitigation measures; (2) lower carbon productivity, which is measured by carbon intensity of the economy and energy intensity of the economy; (3) lower carbon consumption, which is measured by per capita GHG emissions; (4) lower carbon resourcing, which is measured by the proportion of renewables and carbon-free energy to total primary energy, and carbon intensity of energy supply; and (5) lower carbon sector growth, which is measured by growth in green jobs, defined as the 'net direct job-creation in the formal economy across a wide range of technologies/activities that may be classified as green or contributing to the greening of the economy' (DEA 2015). The indicators presented above are relevant for tracking mitigation actions, and are quantifiable and precise. (South Africa has set a fixed-level target in its NDC, which means that the most relevant indicator for tracking progress toward the NDC is GHG emissions levels, in the strictest sense.)

\section{Criterion 2: The information collected for NDC tracking meets the needs of the indicators outlined in criterion 1}

\section{Score:}

Evidence suggests that criterion 2 is partly met. South Africa's DFFE appears to be cognisant of the need to keep data collection to a minimum and relevant to desired outcomes. For example, the national M\&E framework document of 2015 states that 'climate change M\&E will, to the greatest extent possible, rely on existing data collection and reporting systems', cautioning against reporting fatigue and duplication of effort (DEA 2015). DFFE does, however, encounter problems in collecting data. For example, South Africa's first annual climate change report, published in 2016, states that 'there is a dire need for key climate change response ac- tors, including government departments (national, provincial, and local), industry and NGOs to collect, measure and monitor primary output data on climate-related projects and programmes more effectively and systematically' (DEA 2016). This message is echoed by interviewees, with some government officials describing problems they are encountering, such as poor quality data, information not being provided in the correct format, or entities not willing to share their data. According to one interviewee, problems with 'data quality, access, timeliness, appropriateness, and consistency' are all issues that DFFE is currently dealing with.

\section{Criterion 3: There is legislative support for collecting data for NDC tracking and protecting confidential information}

\section{Score:}

Evidence suggests that criterion 3 is fully met. South Africa has established legal regulations to collect emissions data from companies (RSA 2017a). The basis is South Africa's Air Quality Act of 2004, which put in place measures for the prevention of pollution, and standards for the regulation of air quality in the country. It authorises the Minister of Environmental Affairs (later to become the Minister of Forestry, Fisheries and the Environment) to enforce its provisions through the issuance of policy documents and regulations. In July 2017, the Minister defined six GHGs as 'priority pollutants' under the Air Quality Act. This resulted in regulations that mandated companies that exceed emissions 0.1 $\mathrm{MtCO}_{2} \mathrm{e}$ annually to prepare and submit pollution prevention plans to the Minister for approval (RSA $2017 \mathrm{~b}$ ). The regulations also contain a provision for the protection of information stating that information obtained in terms of the regulations will be kept confidential' (Chapter 4 of the regulations, paragraph 7) (RSA 2017b). South Africa is also likely to soon adopt a Climate Change Bill, which will provide an additional legal basis for comprehensive climate action (RSA 2018b). This includes updating the long-term national emissions trajectory, the allocation of sectoral emissions targets, and the regulation of large emitters including through carbon budgets (Presidency of South Africa 2019).

\section{Criterion 4: The government can evaluate progress toward the NDC mitigation target by using outputs from the monitoring and evaluation system}

\section{Score: $\bigcirc$}

Evidence suggests that criterion 4 is fully met. South Africa has an absolute-level NDC mitigation target, which means that, in the strictest sense, progress toward the NDC will be assessed by comparing cur- 
rent emissions levels against a target level of emissions i.e., South Africa can compare its most recent GHG inventory against the 2030 target level of 398$614 \mathrm{MtCO}_{2} \mathrm{e}$. South Africa's GHG inventory is already produced by the $M \& E$ system.

Criterion 5: The government and relevant actors can understand the ambition of, and progress towards, mitigation targets, actions, and measures

Score:

Evidence suggests that criterion 5 is fully met. From an international standpoint, South Africa currently complies with the reporting requirements of the UNFCCC through the submission of national inventory reports and biennial update reports, as well as participation in the technical analysis and facilitative sharing of views. From a domestic standpoint, DFFE produces several additional climate change reports to enhance transparency (i.e., to better understand ambition and progress on climate actions), including the annual climate change reports (DEA 2016; DEA 2017b) and the web-based policy evaluation tracking tool that presents South Africa's GHG emissions levels and the impacts of major policies and measures (which is still under development).

\section{Criterion 6: The government can quantify the socio-economic impacts resulting from climate mitigation actions}

\section{Score:}

Evidence suggests that criterion 6 is partly met. South Africa has designed its M\&E system to produce information on 'wider impacts' of mitigation actions, which is intended to provide a broader narrative surrounding mitigation actions in South Africa (DEA 2019b). While South Africa is clearly demonstrating an intention to quantify and communicate information on the links between climate mitigation efforts and national social and economic impacts, this is not yet occurring in all cases. For example, South Africa's latest biennial update report includes the GHG emissions impacts of many mitigation actions but does not provide information on costs of these actions or impacts on jobs, apart from the occasional reference to general 'job creation'. Moreover, South Africa states that it tracks the 'cost effectiveness' and 'job creation effectiveness' of mitigation actions as part of the M\&E system (DEA 2015), but is yet to publish any information related to these indicators. It does, however, appear that there is a separate precedent for quantifying and reporting socio-economic impacts of climate mitigation actions in South Africa (i.e., apart from the M\&E system). For example, South Africa's Dep- artment of Planning, Monitoring, and Evaluation (DPME) has examined the socio-economic impacts of two new major pieces of South Africa's climate change response - the Climate Change Bill (DPME 2017a) and the carbon tax (DPME 2017b).

\section{Criterion 7: The government presents information that would enable an assessment of whether the country is on track to achieve the NDC or, as a proxy, on track to achieve the Copenhagen pledge}

score: $\bigcirc$

Evidence suggests that criterion 7 is fully met. South Africa is on track to meet its Copenhagen Pledge, which calls for a $34 \%$ emission reduction below business-as-usual levels by 2020 (DEA 2010). While not communicated internationally, the South African government did publish numbers associated with the 'peak, plateau, and decline' emissions trajectory, on which the Copenhagen Pledge is based. The target emissions level for 2020 is 583 $\mathrm{MtCO}_{2} \mathrm{e}^{2}$ South Africa's emissions, including forestry and other land use (FOLU) were $512 \mathrm{MtCO}_{2} \mathrm{e}$ in 2015 and $426 \mathrm{MtCO}_{2} \mathrm{e}$ in 2000 (DEA 2019b). Assuming emissions continue to rise at the same rate between 2015 and 2020, South Africa's emissions in 2020 would be lower than the Copenhagen target (being possibly around $541 \mathrm{MtCO}_{2} \mathrm{e}$ in 2020).

\section{Criterion 8: The NDC tracking process is iterative and information is used to adjust its course}

Score:

Evidence suggests that criterion 8 is partly met. It is clear that South Africa intends to use the outputs from the M\&E system to inform policy direction, including by introducing the concept of 'feedback and learning' (DEA 2014). There is, however, no published evidence to suggest that climate change $M \& E$ directly induces changes in national policy. Specifically, the government has not included any mention of changes to climate change policy that resulted from the M\&E system in any official document published since 2011. Here is an illustrative example: an external study commissioned by DFFE in 2018 concluded that South Africa is on track to meet its NDC mitigation target with current policies and that the implementation of additional mitigation policies will result in positive development benefits for the country (EScience Associates and Energy Research Centre 2018). Since this study was commissioned by DFFE, presumably it will inform the revised NDC that South Africa submits to the UNFCCC in 2020. South Africa's president has already signalled that work to enhance the NDC is underway (Presidency of South Africa 2019), but it 
is not yet clear to the public if the outputs of this study (or others) will inform the revised contribution. $^{3}$

\subsection{Summary}

The evaluation shows that South Africa is already fully meeting criteria in several areas of NDC tracking. The government has established a well-defined vision for climate action, including setting an absolute-level mitigation target in its NDC, which makes tracking progress toward this target much easier. The mitigation indicators are easy to understand and relevant to NDC tracking. There also legislative support for the collection and protection of information. Moreover, evidence suggests that the outputs produced from South Africa's M\&E system do enhance transparency and will allow the government to evaluate progress toward the NDC target. South Africa also is on track toward achieving its Copenhagen pledge. A summary of the evaluation is presented in Table 3.

\section{Table 3: Effectiveness of NDC tracking in} South Africa.

Outcome criteria
Criterion 1: The indicators for NDC tracking
are relevant to the desired outcome, and are
precise and measurable

Criterion 2: The information collected for NDC tracking meets the needs of the indicators outlined in criterion 1

Criterion 3: There is legislative support for collecting data for NDC tracking and protecting confidential information

Criterion 4: The government can evaluate progress toward the NDC mitigation target by using outputs from the monitoring and evaluation system

Criterion 5: The government and relevant actors can understand the ambition of, and progress towards, mitigation targets, actions, and measures

Criterion 6: The government can quantify the socio-economic impacts resulting from climate mitigation actions

Criterion 7: The government presents information that would enable an assessment of whether the country is on track to achieve the NDC or, as a proxy, on track to achieve the Copenhagen pledge

Criterion 8: The NDC tracking process is iterative and information is used to adjust its course
3.4 Options for improving tracking of progress

The results highlighted some areas that can be improved upon to make NDC tracking in South Africa more effective: (1) information collection (as criterion 2 is partly met); (2) links between climate mitigation efforts and socio-economic outcomes (as criterion 6 is partly met); and (3) iteration to make stronger links between the outputs of the NDC tracking work and changes in national policy (as criterion 8 is partly met). The recommendations offered here are based on academic literature, content analysis of key documents, and findings from the in-depth interviews.

\subsubsection{Improving information collection and reporting} In South Africa, mitigation-related data is often not easily collected or willingly provided. Data is often not provided in the correct format, and quality remains a challenge. These factors limit DFFE's ability to conduct robust $\mathrm{M} \& \mathrm{E}$, which has a knock-on effect on other aspects of the department's climate change work. DFFE has improved data quality and collection in recent years, largely through the introduction of the National GHG Emission Reporting Regulations and Pollution Prevention Plans in 2017 (RSA 2017a; RSA 2017b). The amendment to the National GHG Emission Reporting Regulations proposed in September 2019 (DEA 2019a) is also likely to result in positive changes. Among other matters, the amendment calls for GHG emissions reporting at both the data provider level and at facility level, which will improve the granularity of data collected. The amendment requires more complete reporting, covering all process, fugitive, and combustion emissions. The amendment may also improve data quality, as it allows data providers an opportunity to request a review of the applicable emission factor(s) and to transition to better calculation methodologies over time. The carbon tax introduced in June 2019 provides additional impetus for better company-level reporting, providing a five percent carbon budget allowance for data providers that comply with reporting requirements (RSA 2019). It is within this context that the following recommendations are offered to improve DFFE's data collection and reporting efforts.

The first recommendation is to strive to make data collection processes more streamlined. While information collection is as simple as possible, the research pointed to improvements in collecting data more effectively and systematically. Future facility-level reporting should assist with collecting information from heavy-emitting industry. Longstanding memorandums of understanding with key government departments, like the Department of Mineral Resources and Energy, can help provide a legal backbone for information solicitation requests 
(Interview 2). DFFE too often needs to rely on 'humble requests' (Interview 2), 'knocking on doors' (Interview 3), and existing personal relationships with colleagues in other government departments (Interview 1) in order to collect data.

The second (and related) recommendation is to speed up the transition toward an online and automatic information collection system. DFFE currently relies heavily on manual and legacy information systems, which is time-consuming and can contribute to poor data quality (Interview 4). While the eventual idea is to have an online portal to capture reporting submissions from companies, this has not yet materialised (Interview 8).

The third recommendation is to provide training on the information and reporting requirements for the M\&E system. The in-depth interviews revealed that large organisations have capacity and experience in reporting GHG emissions and mitigation potential data. Indeed, these organisations have been reporting on climate change issues for many years via annual reports, the CDP, and to government. But smaller organisations have less experience and less capacity (Interviews 1, 3, 5, 6, $8,11)$. The same is true for municipalities (Interviews 5,6 ). These groups should be focused on for future training. At the same time, learning must also occur within DFFE as it implements the M\&E system (Interview 3).

The fourth recommendation is to begin to practise implementing the NDC tracking requirements called for under the MPGs (UNFCCC 2018, Chapter III.C). This includes progress toward targets, which are tracked using 'relevant' indicators (paragraph 65) and reported in the form of a 'structured summary' (paragraph 77), as well as progress toward mitigation policies and measures (paragraph 80), which are reported in a tabular format (paragraph 82). The structured summary is a key tool for tracking progress, although the quality of information depends on underlying methodologies (Winkler at al. 2019). The MPGs also request the Subsidiary Body for Scientific and Technological Advice to develop 'common tabular formats' (CTFs) for the reporting of information on tracking progress (among others), including the structured summary, to be adopted by COP26 in 2020 (UNFCCC 2018, paragraph 12(a)). Researchers have offered suggestions on what the CTFs may look like in preparation for this meeting (for example, see Winkler et al. 2019; Rocha and Ellis 2020).

The final recommendation is to work on building trust and relations between the government and private sector, which are currently quite poor (Interviews 3, 8, 11). Studies have shown that if entities are transparent about their reasons for collecting data, and offer fair value ${ }^{4}$ in return for it, they will be trusted and will earn ongoing and even expanded access (Morey et al. 2015). Accordingly, DFFE may wish to invest in communications efforts that are targeted at explaining the purposes of data collection and how it is used. Here it will be also important to underscore that information is collected only as strictly necessary.

\subsubsection{Demonstrating ties between climate mitigation and socio-economic outcomes}

South Africa's current response to climate change is framed through a development/socio-economic lens. The 2011 national climate change response white paper, for example, outlines a vision for climate change action that 'enables economic, social and environmental development to proceed in a sustainable manner' (RSA 2011). And the strategic approach is one that 'prioritises climate change responses that have both significant mitigation and adaptation benefits, and that also have significant economic growth, job creation, public health, risk management and poverty alleviation benefits' (RSA 2011). The metrics that have been selected for measuring progress toward South Africa's climate change goals include 'cost-effectiveness' and 'jobcreation-effectiveness' (DEA 2015). While it is clear that South Africa intends to prioritise climate actions that deliver positive socio-economic outcomes, DFFE is not yet effectively communicating information about climate mitigation and development linkages - yet this information is available. For example, several recent research studies have assessed the economic and employment impacts of a low-carbon transition in South Africa. One study concluded that there will be positive impacts on employment and gross domestic product when planned key mitigation policies are implemented in combination (EScience Associates and Energy Research Centre 2018). Additionally, a separate study also shows that South Africa faces a significant financial risk due to its heavy economic reliance on coal, but there are measures to mitigate this risk and, indeed, ways to find opportunities to capitalise on this transition. This includes new markets for minerals used in low-carbon technologies (for example, platinum and manganese), and the creation of new jobs in industries that are more resilient to, or would even benefit from, a low-emissions economy (Huxman et al. 2019).

The South African government has also examined the socio-economic impacts of two new major pieces of South Africa's climate change response the Climate Change Bill (DPME 2017a) and the carbon tax (DPME 2017b). The Department of Planning, Monitoring, and Evaluation (DPME) investigated several different areas as part of this work, including the groups that will benefit from these new laws, those that will bear the costs, and means of managing perceived risks. Regarding the 
Climate Change Bill, the exploratory work of the DPME found that this legislation would benefit the poorest and most vulnerable, would foster social cohesion, enhance security (safety, financial, food, energy), improve inequality, support job creation, and support environmental sustainability. The only downside is that GDP may be negatively impacted in the short term as heavy-emitting industries bear the financial impacts of climate action, but these impacts are expected to be marginal, as the benefits of the transitioning to a low-emissions society far outweigh the costs over the long run. The DPME's work on assessing the Climate Change Bill also notes that the government and stakeholders will benefit from 'ongoing research into the economic and social costs and benefits of implementing the adaptation and mitigation measures proposed in the Bill, as the instruments evolve and are implemented and revised over time'. Regarding the carbon tax, the DPME reaches similar conclusions. There will generally be an improvement in socio-economic factors as a result of implementing the carbon tax, and the marginal impact on GDP can be mitigated through a gradual phase-in of the tax coupled with revenue recycling. The DPME also underscores the key role of M\&E in implementing the carbon tax, which can help set sector benchmarks, quantify mitigation potentials, and identify areas for additional research.

In sum, it is clear that the DPME and outside researchers are already identifying and quantifying the positive development benefits associated with climate mitigation, yet these benefits are not yet being described as part of South Africa's formal climate change reporting - either internationally in BURs, or domestically in annual climate change reports. The key recommendation is therefore for DFFE to (1) identify suitable indicators for measuring progress on key socio-economic indicators to be included in the national M\&E system, in line with the objectives of the 2011 national climate change response white paper (i.e., going beyond indicators of 'cost-effectiveness' and 'job-creation-effectiveness'); and (2) begin reporting on the impacts of climate mitigation actions on these indicators.

\subsubsection{Making tracking iterative and performance- oriented}

The results revealed that there is no evidence to suggest that the outputs of South Africa's M\&E system inform policy direction and changes, despite good intentions for them to do so. One government official currently working on M\&E in South Africa suggests that the reason there are not better links between outputs and policy change is that the current outputs do not provide enough information on the 'how' and the 'why' of mitigation actions succeeding or failing (Interview 3). The key recommendation is, therefore, that the outputs from South Africa's M\&E system, including NDC tracking, should provide useful information that can inform decision- and policy-making. If certain mitigation policies and actions are not delivering the expected results, there will be course corrections along the way; similarly, if policies are producing excellent outcomes, this learning will be capitalised upon and employed in other areas.

\section{Conclusion}

This paper presented a qualitative, multi-criteria framework that can be used to either design effective NDC tracking systems or evaluate the extent to which Parties are prepared for NDC tracking, complementing the international NDC tracking and reporting rules agreed to in 2018. The framework is applied ex ante, as the Paris Agreement's enhanced transparency framework only comes into effect in 2024. In future, the framework of indicators for mitigation might be applied for ex post evaluation, as part of a country's broader M\&E system.

The framework was applied to an in-depth case study on South Africa. The evaluation showed that South Africa is already progressing well in several areas of NDC tracking, but can improve in others. South Africa has set mitigation indicators that are easy to understand and relevant to NDC tracking. There is legislative support for collecting and protecting information. Evidence suggests that the outputs produced from South Africa's M\&E system do enhance transparency and will allow the government to evaluate progress toward the NDC target. South Africa can enhance its domestic arrangements for NDC tracking by improving data collection, by demonstrating the links between climate action and socio-economic outcomes, and by making changes in national policy in response to the outputs of M\&E system.

South Africa has a fairly advanced M\&E system, which was formally established in 2011, primarily in response to domestic objectives. South Africa is also a regular submitter of BURs to the UNFCCC, so the country is considered to be fairly advanced in terms of international reporting too. As such, the findings of this paper would suggest that other developing country Parties may also require additional resources and capacity to track NDCs effectively.

\section{Author contributions}

K. Ross coordinated the analysis, wrote the paper, and created the figures. H. Winkler contributed to the analysis and article review.

\section{Notes}

1. Other parts of Article 13 referring to NDCs are not specified as clearly, and are capable of the broader interpretation of NDCs (Winkler et al. 2017). 
2. While DFFE has removed the 'peak, plateau and decline' trajectory graphic from its website, it is still available for searching online.

3. In September 2019, in a statement to the United Nations' Secretary General, South Africa's President Cyril Ramaphosa committed to enhancing the current mitigation contribution of South Africa's NDC before the end of 2020. According to the statement, this will be achieved by decommissioning old coal powered plants, adding renewable energy capacity, and minimising the environmental impact of mining (in addition to the implementation of current mitigation policies and actions). The statement also goes on to note that 'additional mitigation ambition by 2030 will require a bold programme which targets our key emissions source, the electricity sector, and goes beyond current plans to invest further in renewable energy' (Presidency of South Africa 2019).

4. 'Value' here is not intended in the monetary sense.

\section{References}

Aldy, J. 2014. The Crucial Role of Policy Surveillance in International Climate Policy. Climatic Change 126 (2014): 279292. https://doi.org/10.1007/s10584-014-1238-5

Aldy, J. and Pizer, W. 2016. Alternative Metrics for Comparing Domestic Climate Change Mitigation Efforts and the Emerging International Climate Policy Architecture. Review of Environmental Economics and Policy 10 (1): 3-24. https://doi.org/10.1093/reep/rev013

Bodansky, D. and Diringer. E. 2014. Building Flexibility and Ambition into a 2015 Climate Agreement. Arlington: Center for Climate and Energy Solutions. https://www.c2es.org/site/assets/uploads/2014/06/building-flexibility-ambition-2015-climate-agreement.pdf

Briner, G. and Moarif, S. 2016. Unpacking Provisions Related to Transparency of Mitigation and Support in the Paris Agreement. Paris: Organisation for Economic Cooperation and Development and International Energy Agency. http://www.oecd.org/environment/cc/Unpacking-transparency-provisions-Paris-Agreement-CCXG-May2016.pdf

Breidenich, C. and Bodansky, D. 2009. Measurement, Reporting, and Verification in a Post-2012 Climate Agreement. Arlington: Pew Center on Global Climate Change. https://www.c2es.org/site/assets/uploads/2009/04/mrv-post2012-climate-agreement.pdf

CAIT Climate Data Explorer. 2020. (Database) Historical Emissions. Accessed 3 October 2019. http://cait.wri.org/historical/

Dagnet, Y., Rocha, M., Fei, T. and Elliott, C. 2017a. Mapping the Linkages between the Transparency Framework and Other Provisions of the Paris Agreement. Washington, D.C.: Project for Advancing Climate Transparency (PACT). https://wriorg.s3.amazonaws.com/s3fs-public/mapping-linkages-between-transparency-framework-other-provisions-paris-agreement.pdf

Dagnet, Y., van Asselt, H., Cavalheiro, G., Rocha, M., Bisiaux, A. and Cogswell, N. 2017b. Designing the Enhanced Transparency Framework Part 2: Review Under the Paris Agreement. Washington, D.C.: PACT. https://www.transparency-partnership.net/system/files/document/WRI\%20PACT_2017_Review\%20under\%20the\%20Paris\%20Agreement.pdf

DEA [Department of Environmental Affairs]. 2010. South Africa's Copenhagen Pledge. Pretoria: Department of Environmental Affairs.

https://unfccc.int/files/meetings/cop_15/copenhagen_accord/application/pdf/southafricacphaccord_app2.pdf

DEA [Department of Environmental Affairs]. 2014. South Africa's First Biennial Update Report. Pretoria: Department of Environmental Affairs. https://unfccc.int/sites/default/files/resource/rsabur1.pdf.

DEA [Department of Environmental Affairs]. 2015. The National Climate Change Response Monitoring and Evaluation System Framework. Pretoria: Department of Environmental Affairs. https://www.environment.gov.za/sites/default/files/reports/nationalclimatechangeresponse_MESF.pdf

DEA [Department of Environmental Affairs]. 2016. South Africa's First Annual Climate Change Report. Pretoria: Department of Environmental Affairs. https://www.environment.gov.za/otherdocuments/reports/southafricas_firstnational_climatechange

DEA [Department of Environmental Affairs]. 2017a. South Africa's Second Biennial Update Report. Pretoria: Department of Environmental Affairs. https://unfccc.int/files/national_reports/nonannex_i_parties/biennial_update_reports/application/pdf/south_africa_2nd_bur.pdf

DEA [Department of Environmental Affairs]. 2017b. South Africa's Second Annual Climate Change Report. Pretoria: Department of Environmental Affairs.

https://www.environment.gov.za/sites/default/files/reports/southafrica_secondnational_climatechnage_report2017.pdf

DEA [Department of Environmental Affairs]. 2019a. National Environmental Management: Air Quality Act, 2004 (Act No. 39 Of 2004). Proposed Amendment of The National Greenhouse Gas Emission Reporting Regulations. Pretoria: Government Gazette. 13 September 2019. https://www.gov.za/sites/default/files/gcis_document/201909/42697gon1154.pdf

DEA [Department of Environmental Affairs]. 2019b. South Africa's Third Biennial Update Report to the United Nations Framework Convention on Climate Change. Pretoria: Department of Environmental Affairs. https://unfcc.int/sites/default/files/resource/Final\%203rd\%20BUR\%20of\%20South\%20Africa\%20100.pdf 
DEA [Department of Environmental Affairs]. 2019c. GHG National Inventory Report: South Africa, 2000-2015. Pretoria: Department of Environmental Affairs. https://unfccc.int/sites/default/files/resource/South\%20Africa\%20NIR\%20\%20to\%20BUR3\%20\%202000\%20-\%202015\%20GHG\%20Inventory\%20v2.pdf

DPME [Department of Planning, Monitoring, and Evaluation]. 2017a. Final Impact Assessment: Climate Change Bill. Pretoria: Department of Planning, Monitoring, and Evaluation. https://www.environment.gov.za/sites/default/files/docs/seia_climatebill.pdf

DPME [Department of Planning, Monitoring, and Evaluation]. 2017b. Final Impact Assessment: Carbon Tax. Pretoria: Department of Planning, Monitoring, and Evaluation. http://www.treasury.gov.za/public\%20comments/CarbonTaxBll2017/Annexure $\% 202 \% 20$ Socioeconomic\%20Impact $\% 20$ Assessment $\% 20$ \%20Carbon\%20Tax\%20Bill\%202017.pdf

Ellis, J. and Moarif, S. 2009. GHG Mitigation Actions: MRV Issues and Options. Paris: Organisation for Economic Cooperation and Development and International Energy Agency. https://www.oecdilibrary.org/docserver/5k4695890xd6-en.pdf?expires=1584572696\&id=id\&accname=guest\&checksum=D545B3DB13669677CE12CDB12993BBB5

EScience Associates and Energy Research Centre. 2018. Policies and Measures: Estimating the Individual and the Total Effect of Policies and Measures to Reduce Greenhouse Gas Emissions and the Socio-Economic Impact of the Response Measures for South Africa (Draft). Cape Town: EScience Associates and Energy Research Centre. https://www.environment.gov.za/sites/default/files/docs/policyandmeasures_draftreport.pdf.

Fransen, T. 2009. Enhancing Today's MRV Framework to Meet Tomorrow's Needs: The Role of National Communications and Inventories. Washington DC: World Resources Institute. https://wriorg.s3.amazonaws.com/s3fs-public/national_communications_mrv.pdf

G77 \& China (Group of 77 and China). 2015. Statement on Behalf of the Group of 77 and China by South Africa at the Closing Plenary of the 21st Conference of the Parties to the United Nations Framework Convention on Climate Change (COP21), Paris Climate Change Conference (Paris, France, 12 December 2015). Accessed 15 October 2019. https://www.g77.org/statement/getstatement.php?id=151212

Höhne, N., den Elzen, M., Rogelj, J., Metz, B., Fransen, T., Kuramochi, T., Olhoff, A., Alcamo, J., Winkler, H., Fu, S., Schaeffer, M., Schaeffer, R., Peters, G. P., Maxwell, S. and Dubash, N.K. 2020. Emissions: world has four times the work or one-third of the time. Nature Comment 579 (March): 25-28.

Hood, C. and Soo, C. 2017. Accounting for Mitigation Targets in Nationally Determined Contributions under the Paris Agreement. Paris: Organisation for Economic Cooperation and Development/ International Energy Agency. https://www.oecd.org/environment/cc/Accounting-for-mitigation-targets-in-Nationally-Determined-Contributions-under-the-Paris-Agreement.pdf

Huxman, M., M. Anwar, and D. Nelson. 2019. Understanding the Impact of a Low Carbon Transition on South Africa. London: Climate Policy Initiative. https://climatepolicyinitiative.org/publication/understanding-the-impact-of-alow-carbon-transition-on-south-africa/.

IPCC [Intergovernmental Panel on Climate Change]. 2006. 2006 IPCC Guidelines for National Greenhouse Gas Inventories. Geneva: World Meteorological Organization/United Nations Environment Programme. https://www.ipccnggip.iges.or.jp/public/2006gl/

Klostermann, J., van de Sandt, K., Harley, M., Hildén, M., Leiter, T., van Minnen, J., Pieterse, N. and van Bree, L. 2018. Towards a Framework to Assess, Compare and Develop Monitoring and Evaluation of Climate Change Adaptation in Europe. Mitigation and Adaptation Strategies for Global Change 23: 187-209. https://doi.org/10.1007/s11027015-9678-4

Kusek, J. and Rist, R. 2004. Ten Steps to a Results-Based Monitoring and Evaluation System. Washington, D.C.: World Bank. https://openknowledge.worldbank.org/bitstream/handle/10986/14926/296720PAPER0100steps.pdf

Levin, K., Finnegan, J., Rich, D. and Bhatia, P. 2014. Mitigation Goal Standard. Washington D.C.: Greenhouse Gas Protocol. https://wriorg.s3.amazonaws.com/s3fs-public/Mitigation_Goal_Standard.pdf.

Markkanen, S. and Anger-Kraavi, A. 2019. Social Impacts of Climate Change Mitigation Policies and Their Implications for Inequality. Climate Policy 19 (7): 827-844. https://doi.org/10.1080/14693062.2019.1596873

Moarif, S. 2017. Information Needed to Facilitate the Clarity, Transparency and Understanding of Mitigation Contributions. France: Climate Change Expert Group, Organisation for Economic Cooperation and Development/ International Energy Agency. https://www.oecd.org/environment/cc/Information-needed-to-facilitate-the-CTUof-mitigation-contributions.pdf

Morey, T., Forbath, T. and Schoop, A. 2015. Customer Data: Designing for Transparency and Trust. Harvard Business Review, May 2015. https://hbr.org/2015/05/customer-data-designing-for-transparency-and-trust.

Morra Imas, L. and Rist, R. 2009. The Road to Results: Designing and Conducting Effective Development Evaluations. Washington, D.C.: The World Bank. http://documents.worldbank.org/curated/en/400101468169742262/pdf/The-road-to-results-designing-and-conducting-effective-developmentevaluations.pdf

Pew Center 2010. MRV: A Survey of Reporting and Review in Multilateral Regimes. Arlington: Pew Center on Global Climate Change. http://www.pewclimate.org/docUploads/survey-reporting-review-multilateral-regimes.pdf 
Presidency of South Africa. 2019. Statement by H.E. President Cyril Ramaphosa of South Africa to the United Nations Secretary-General's Climate Summit, 23 September 2019. Pretoria: Department of International Relations and Cooperation (DIRCO). Accessed on 12 October 2019. http://www.dirco.gov.za/docs/speeches/2019/cram0923.htm

Rennkamp, B. and Marquard, A. South Africa's Multiple Faces in Current Climate Clubs. South African Journal of International Affairs 24 (4): 443-461. https://doi.org/10.1080/10220461.2017.1421479

Rocha, M. and Ellis, J. 2020 Reporting progress towards Nationally Determined Contributions: Exploring Possible Common Tabular Formats for the Structured Summary. Paris: Organisation for Economic Cooperation and Development/International Energy Agency. https://www.oecd-ilibrary.org/environment/reporting-progresstowards-nationally-determined-contributions_a23de32d-en

RSA [Government of the Republic of South Africa]. 2011. National Climate Change Response White Paper. Pretoria: Department of Environmental Affairs. https://www.environment.gov.za/sites/default/files/legislations/national_climatechange_response_whitepaper.pdf

RSA [Government of the Republic of South Africa]. 2015. South Africa's Intended Nationally Determined Contribution (INDC). Pretoria: Government of the Republic of South Africa. https://www4.unfccc.int/sites/ndcstaging/PublishedDocuments/South\%20Africa\%20First/South\%20Africa.pdf

RSA [Government of the Republic of South Africa]. 2017a. National Environmental Management: Air Quality Act (39/2004): National Greenhouse Gas Emission Reporting Regulations. Pretoria: Government Gazette. https://www.environment.gov.za/sites/default/files/legislations/nemaqa39of2004_nationalgreenhousegasemissionreporting_gn40762_0.pdf

RSA [Government of the Republic of South Africa]. 2017b. National Pollution Prevention Plan Regulations. Pretoria: Government Gazette. https://www.environment.gov.za/sites/default/files/legislations/nemaqa39of2004_nationalpollutionpreventionplansregulations_gn40996_0.pdf

RSA [Government of the Republic of South Africa] 2018a. South Africa's Low-Emission Development Strategy 2050 (Draft). Pretoria: Government of the Republic of South Africa. https://www.environment.gov.za/sites/default/files/strategic_plans/southafricas_lowemission_developmentstrategy_dec2018draft.pdf

RSA [Government of the Republic of South Africa]. 2018b. Climate Change Bill, 2018: For public comment. Pretoria: Government Gazette. https://www.environment.gov.za/sites/default/files/legislations/climatechangebill2018_gn41689.pdf

RSA [Government of the Republic of South Africa]. 2018c. Presidential Jobs Summit Framework Agreement. Pretoria: Government of the Republic of South Africa. https://www.gov.za/sites/default/files/gcis_documents/Jobs_Summit_FrameWork_Agreement.pdf

RSA [Government of the Republic of South Africa]. 2019. President Cyril Ramaphosa signs 2019 Carbon Tax Act into law. South African Government, 26 May 2019. https://www.gov.za/speeches/publication-2019-carbon-tax-act-26may-2019-0000.

Stevens, S. 1946. On the Theory of Scales of Measurement. Science, New Series 103 (1946): 677-680. https://www.jstor.org/stable/1671815

Trutnevyte, E., Hirt, L., Bauer, N., Cherp, A., Hawkes, A., Edelenbosch, O., Pedde, S. and van Vuuren, D. 2019. Societal Transformations in Models for Energy and Climate Policy: The Ambitious Next Step. One Earth 1 (4): 423-433. https://doi.org/10.1016/j.oneear.2019.12.002.

UNFCCC [United Nations Framework Convention on Climate Change]. 2007. Decision 1/CP.13, Bali Action Plan in Report of the Conference of the Parties on its thirteenth session. FCCC/CP/2007/6/Add.1, 14 March 2008. Bonn: UNFCCC. https://unfccc.int/resource/docs/2007/cop13/eng/06a01.pdf.

UNFCCC [United Nations Framework Convention on Climate Change]. 2011.Decision 1/CP.17, Establishment of an Ad Hoc Working Group on the Durban Platform for Enhanced Action. Document FCCC/CP/2011/9/Add.1, 15 March 2012. https://unfccc.int/resource/docs/2011/cop17/eng/09a01.pdf

UNFCCC [United Nations Framework Convention on Climate Change]. 2015. Paris Agreement, Annex to decision 1/CP.21. Document FCCC/CP/2015/10/Add.1, 29 January 2016. Bonn: UNFCCC. http://unfccc.int/resource/docs/2015/cop21/eng/10a01.pdf\#page=2

UNFCCC [United Nations Framework Convention on Climate Change]. 2018. Decision 18/CMA.1, with Annex: Modalities, Procedures and Guidelines for the Transparency Framework for Action and Support Referred to in Article 13 of the Paris Agreement Document FCCC/PA/CMA/2018/3/Add.2, 19 March 2019. Bonn: UNFCCC. https://unfccc.int/sites/default/files/resource/cma2018_3_add2\%20final_advance.pdf

UNFCCC [United Nations Framework Convention on Climate Change]. 2020. Biennial Update Report submissions from Non-Annex I Parties. Accessed on 11 March 2020. https://unfccc.int/BURs

Weiner, J. 2015. Towards an Effective System of Monitoring, Reporting, and Verification. In Toward a Workable and Effective Climate Regime. Barrett, C., Carraro, C. and de Melo, J. (eds.) 183-200. London: Centre for Economic Policy Research Press.

Winkler, H., Mantlana, B. and Letete, T. 2017. Transparency of Action and Support in the Paris Agreement. Climate Policy 17 (7): 853-872. https://doi.org/10.1080/14693062.2017.1302918 
Winkler, H., Marquard, A. and Motshwanedi, S. 2019. Tracking Progress. Policy brief. Energy Research Centre, University of Cape Town, Cape Town, South Africa. http://webcms.uct.ac.za/sites/default/files/image_tool/images/119/ PB\%20on\%20tracking\%20progress\%20April\%202019.pdf 